\title{
Normal MPS excretion, but dermatan sulphaturia, combined with a mild Maroteaux-Lamy phenotype
}

\author{
T Tønnesen, H N Gregersen, F Güttler
}

\begin{abstract}
A mildly affected Maroteaux-Lamy patient is described. Electrophoretic separation of acid mucopolysaccharides (MPS) in the urine showed an increased excretion of dermatan sulphate in spite of a normal total excretion of MPS.
\end{abstract}

Mucopolysaccharidosis VI, Maroteaux-Lamy syndrome, is caused by a deficiency of the lysosomal enzyme arylsulphatase B ( $\mathrm{N}$-acetylgalactosamine-4sulphatase). ${ }^{1-4}$ The enzyme locus has been assigned to $5 \mathrm{q} 11-\mathrm{q} 13 .^{5}$

Severe, mild, and intermediate phenotypes have been observed. The severe and the mild forms are probably the result of allelic mutations, and the intermediate form is most likely a genetic compound form. ${ }^{6}$ In all three forms intelligence is normal, although mental retardation has been suggested in a few cases. ${ }^{78}$

In the severe form, growth retardation is apparent at the age of 2 to 3 years. Genu valgum, lumbar kyphosis, and anterior sternal protrusion are gradually progressive thereafter. The face becomes coarse, the corneas become clouded, and articular movement is severely restricted with progressive development of claw hands. Involvement of the heart valves causes the development of murmurs and heart failure. Hydrocephalus and neurological complications caused by hypoplasia of the odontoid process and consequently atlantoaxial subluxation also occur. The hips, specifically the femoral heads, are severely involved. The patients become severely disabled owing to their gross skeletal deformity and usually die before their late twenties.

The John F Kennedy Institute, G1 Landevej 7, DK-2600

Glostrup, Denmark.

T Tønnesen, F Güttler

Department of Orthopaedic Surgery, Aalborg Hospital, Denmark.

H N Gregersen

Correspondence to Dr Tønnesen.

Received for publication 23 October 1990.

Revised version accepted for publication 11 December 1990.
In the mild form, the patients have only mild stiffness of the hands and, apart from short stature, they are without severe skeletal deformities and are, owing to normal intelligence, able to maintain normal life. Bilateral 'Legg-Perthes disease' is seen in childhood and corneal clouding is found in the twenties. The murmur of aortic stenosis can be found in childhood. In both the severe and the mild forms of the disease, mucopolysacchariduria (mainly dermatan sulphate) is found. ${ }^{6} 9$ Two clinically mild patients have been reported with dermatan sulphaturia accompanied by normal MPS excretion. ${ }^{10}$ The residual activity of arylsulphatase B is not correlated with the phenotypic presentation. ${ }^{6}$

In this paper we report a patient with mild Maroteaux-Lamy disease with dermatan sulphaturia combined with normal total excretion of mucopolysaccharides.

\section{Case report}

The proband was a 33 year old male, the first born of three sibs, to non-consanguineous, healthy parents. The two male sibs are normal. At the age of 6 years he was examined in a department of orthopaedic surgery because of pain in both hips and a limping gait. Decreased movements in both hip joints and a slightly increased thoracic kyphosis were found. $X$ rays of both hips showed significant changes both in the femoral heads and in the acetabula. No diagnosis was achieved and no treatment was given, but the patient was advised to avoid heavy work. He completed high school and college with no major problems and was trained as an engineer.

Six years ago the patient was admitted to the department of orthopaedic surgery, Aalborg Hospital with pain in both hips. On examination we found changes in his thoracic spine and in the hips, as mentioned above. $X$ rays showed hip dysplasia on both sides, but no other bone or joint abnormalities were seen. His height was $160 \mathrm{~cm}$ and weight $57 \mathrm{~kg}$. Cardiological and ophthalmological examinations were normal. Histopathology of a skin biopsy was normal. Urine was analysed for MPS and lysosomal enzyme activities were determined. 
Table 1 MPS excretion in urine when the patient was 27 years old. MPS was isolated from a 24 hour urine sample and analysed as previously described. ${ }^{\prime \prime}$ The numbers in brackets represent the mean [SD] for age matched controls. The results for the severe Maroteaux-Lamy patient are taken from Vestermark et al. ${ }^{3}$

\begin{tabular}{lcccccc}
\hline & \multicolumn{5}{c}{ MPS excretion in the urine } \\
\cline { 2 - 6 } & $\begin{array}{c}\text { mg uronic acid/ } \\
\text { g creatinine }\end{array}$ & Ratio & CH & DS & HS \\
\hline $\begin{array}{l}\text { Patient } \\
\begin{array}{l}\text { Severe Maro- } \\
\text { teaux-Lamy } \\
\text { disease }\end{array}\end{array}$ & $4 \cdot 18(2.75[0.55])$ & 0.11 & 40 & 50 & 10 \\
\hline
\end{tabular}

Ratio= ratio of CPC precipitable over CPC non-precipitable MPS. $\mathrm{CH}=$ chondroitin sulphate. $\mathrm{DS}=$ dermatan sulphate. $\mathrm{HS}=$ heparan sulphate.

Table 2 Enzymatic activities of arylsulphatase $B$ and the control enzyme, hexosaminidase, were determined as previously described. ${ }^{8}$ The values represent the mean of a duplicate analysis and are expressed as $\mathrm{nmol} / \mathrm{h} / \mathrm{mg}$ protein. The results for the severe Maroteaux-Lamy patient are taken from Vestermark et al. ${ }^{8}$

\begin{tabular}{lll}
\hline & \multicolumn{2}{c}{$\begin{array}{c}\text { Enzymatic activities of } \\
\text { arylsulphatase B }\end{array}$} \\
\cline { 2 - 3 } & Arylsulphatase B & Hexosaminidase \\
\hline Patient Maroteaux-Lamy & 30 & 7767 \\
$\begin{array}{l}\text { Severe Marotease } \\
\text { diseange }(n=10)\end{array}$ & 41 & 16380 \\
Control range & $280-871$ & $4353-10086$ \\
Control median & 440 & 6486 \\
\hline
\end{tabular}

\section{Results}

When the patient's urine was investigated, the following results were obtained (table 1). The total amount of uronic acid was just above the $99 \%$ limit. For comparison the significantly increased uronic acid excretion from a severe Maroteaux-Lamy patient is shown. The ratio of cetyl pyridinium (CPC) precipitable over CPC non-precipitable MPS, which for normal persons is below 1 , was normal in the patient. For the severe Maroteaux-Lamy patient, as for other mucopolysaccharidosis patients, this ratio is significantly increased. By electrophoretic separation of the MPS, the present patient showed $50 \%$ and the severely affected patient showed $85 \%$ dermatan sulphate. In controls, no more than $15 \%$ dermatan sulphate is usually observed.

Determination of arylsulphatase B activities in the patient's fibroblasts showed a greatly reduced level of activity (table 2). The residual activity was even lower than that of the severe Maroteaux-Lamy patient.

\section{Discussion}

The present patient was thought for many years to suffer from Morquio's syndrome owing to his skeletal $x$ ray changes. He was not properly diagnosed until he was 27 years of age. During these final investigations we found that this patient had dermatan sulphaturia in spite of a normal total MPS excretion and a normal ratio of CPC precipitable over CPC non-precipitable MPS. These two last results are used to exclude a mucopolysaccharidosis in the event that they are both normal. From the electrophoretic separation of MPS, we observed an approximately three fold increase in the amount of dermatan sulphate. This last observation underlines the fact that in cases where clinical suspicion points towards a mucopolysaccharidosis, it is mandatory to perform electrophoretic separation of MPS, even when the total MPS excretion is normal. Normal total MPS excretion was also recently found in a patient with Hunter's disease and $\alpha_{1}$-antitrypsin deficiency. ${ }^{11}$

The residual activity of arylsulphatase $B$ in our patient is very low. The activity is in the same range as in our previously reported mentally retarded Maroteaux-Lamy patient. ${ }^{8}$ This previous patient presented with significantly increased total MPS excretion. We have thus seen the same residual enzyme activity in both a mildly affected and a severely affected patient. This means that there is no strict correlation between the clinical state and the residual enzyme activity in Maroteaux-Lamy syndrome.

Our patient and the two previously published patients ${ }^{10}$ might suggest an additional subgroup with normal total MPS excretion among mildly affected Maroteaux-Lamy patients.

The authors wish to thank the following foundations for financial support: The Foundation of 1870, P Carl Petersen's Foundation, Frantz Hoffmann's MemorialFoundation, and Frode V Nyegaard and Wife's Foundation.

1 Maroteaux P, Levéque B, Maire J, Lamy $M$. Une nouvelle dysotose avec élimination urinaire de chondroitine-sulfate $B$. Presse Med 1963;71:1849-51.

2 Stumpf DA, Austin JH, Crocker AC, La France M. Mucopolysaccharidosis type VI (Maroteaux-Lamy syndrome): sulfatase B deficiency in tissues. Am F Dis Child 1973;126:747-55.

3 O'Brien JF, Cantz M, Spranger J. Maroteaux-Lamy disease, subtype A: deficiency of a $\mathrm{N}$-acetylgalactosamine-4-sulfatase. Biochem Biophys Res Commun 1974;60:1170-7.

4 Matalon R, Arbogast B, Dorfman A. Deficiency of chondroitin sulfate $\mathrm{N}$-acetylgalactose-amine 4 sulfate sulfatase in MaroteauxLamy syndrome. Biochem Biophys Res Commun 1974;61: $1450-7$.

5 Fidzjanska E, Abramowicz T, Czartoryska B, et al. Localization of the human arylsulfatase $B$ gene locus to chromosome 5 by use of hamster-man somatic cell hybrids. 7th International Congress of Human Genetics, Berlin, 1986:611-2.

6 Neufeld EF, Muenzer J. The mucopolysaccharidoses. In: Scriver CR, Beaudet AL, Sly WS, Valle D, eds. The metabolic basis of 
inherited disease. 6th ed. New York: McGraw-Hill, 1989: 1565-87.

7 Taylor HR, Hollows FC, Hopwood JJ, Robertson EF. Report of a mucopolysaccharidosis occurring in Australian aborigines. $\mathcal{7}$ Med Genet 1978;15:455-61.

8 Vestermark S, Tønnesen T, Schultz-Andersen M, Güttler F. Mental retardation in a patient with Maroteaux-Lamy. Clin Genet 1987;31:114-7.

9 Neufeld EF, Barton RW. Genetic disorders of mucopoly- saccharide metabolism. In: Gaul E, ed. Biology of brain dysfunction. Vol 1. New York: Plenum Press, 1972:1-30.

10 Hopwood JJ, Muller V, Harrison WF, et al. Enzymatic diagnosis of the mucopolysaccharidoses. Experience of 96 cases diagnosed in a five-year period. Med f A ust 1982;1:257-60.

11 Nielsen JB, Güttler F, Hobolth N, et al. Normal excretion of urinary acid mucopolysaccharides in a boy with iduronate sulphate deficiency. Hunter phenotype and $\alpha_{1}$-antitrypsin deficiency. Eur $\mathcal{F}$ Pediatr 1986;145:572-5.

\section{Correction}

In the March 1991 issue of the Journal ( $(7$ Med Genet 1991; 28: 169), table 3 in the paper of Zeng et al on 'Analysis of RFLPs and DNA deletions in the Chinese Duchenne muscular dystrophy gene' should have appeared as below.

Table 3 Deletions in the DMD patients relative to exon containing HindIII fragments detected with cDNA probes.

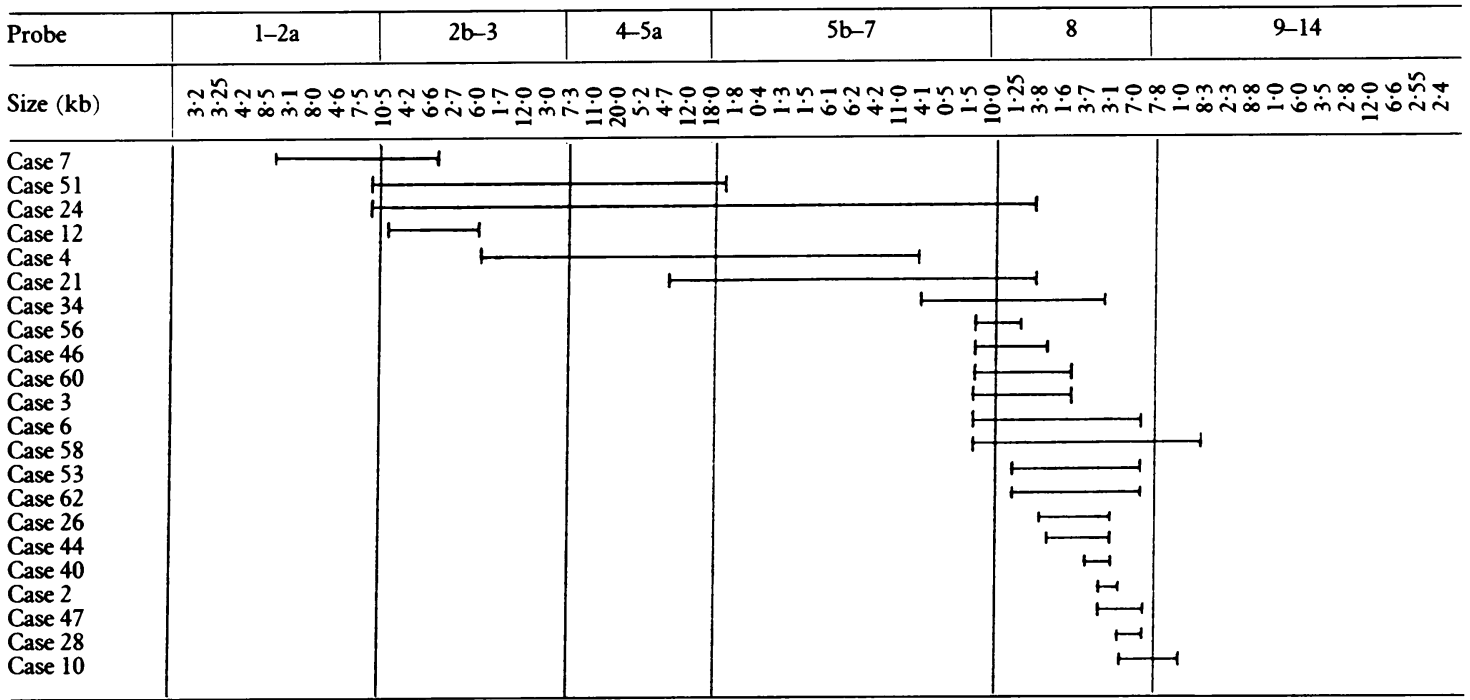

The patients who were subjected to the whole series of cDNA detection are presented. 